\title{
The Effect of Teaching Different Genres on Listening Comprehension Performance of Iranian EFL Students
}

\author{
Bahador Sadeghi (Corresponding Author) \\ English Department, Islamic Azad University, Takestan Branch, Takestan, Iran \\ Mohammad Taghi Hassani \\ Imam Hossein University, Tehran; \\ Islamic Azad University, Takestan Branch, Iran \\ Hessam Noory \\ English Department, Islamic Azad University, Takestan Branch, Takestan, Iran
}

\begin{abstract}
With ever growing need of genre based instruction, it seems listening comprehension is being marginalized in both research and material development of genre based instruction. In this research four genres of narrative, argumentative, descriptive and expository were presented to $23(\mathrm{n}=23)$ male intermediate Iranian EFL students with thorough introduction to each genre. The control group, 22 male intermediate students $(n=22)$ also received the same materials but in random order and without any introduction to genres of the listening input. The results of the study states that genre based listening input and introduction to genres does have positive impact on listening comprehension of Iranian EFL students.
\end{abstract}

Index Terms - genre, listening, listening comprehension, genre based language teaching

\section{INTRODUCTION}

Teaching a second language is an interesting field of study which has engaged many philosophers and researchers to study and to find the best and most effective ways of teaching second language to language learners. Reading, writing, listening and speaking are four major skills in any language and therefore many researches have been conducted to howness and whatness of teaching each of these skills to language learners. This study is an attempt to see if teaching the four genres of narrative, argumentative, Descriptive and expository have any positive effects on listening comprehension of Iranian EFL students. Feyten (1991) claims that more than 45\% of communicating time is spent on listening.

Listening to foreign language authentic materials might cause lots of problems for language learners. "Everyone who has ever learned a foreign language has probably experienced the frustrating feeling of not being able to communicate with native speakers of the language despite years of training in the target language. Often one knows the words when they are presented visually but one does not recognize them in a spoken utterance. The main cause of this communication problem is the disability of listeners to recognize the words in the pace in which they are spoken. In other words, listeners may have enough vocabulary knowledge but they may be unable to use this knowledge under time pressure". (Poelmans, 2003). "In the 1980s, the genre approach became popular along with the notion that student writers could benefit from studying different types of written text". (Lingzhu, 2009).

The teaching of listening has attracted a greater level of interest in recent years than it did in the past (Richards 2008, p.12).There are many reasons for focusing on listening when teaching English as a foreign language, not least of which is the fact that we as humans have been learning languages through our ears for thousands and thousands of years, far longer than we as humans have been able to read. Our brains are well programmed to learn languages through sound and speech. This is not to say that reading and writing are less important, but listening as a gate to speaking and acquiring a language is highlighted. (Alastair Graham-Marr 2004). The teaching of listening has attracted a greater level of interest in recent years than it did in the past. "Now, university entrance exams, exit exams, and other examinations often include a listening component, acknowledging that listening skills are a core component of second-language proficiency, and also reflecting the assumption that if listening isn't tested, teachers won't teach it." (Richards 2008, $p$ 1).

Brown in his research in teaching listening states that "Listening in another language is a hard job, but we can make it easier by applying what we know about activating prior knowledge, helping students organize their learning by thinking about their purposes for listening, and if speaking is also a goal of the classroom, using well-structured speaking tasks informed by research."(Brown 2006, p.1)In teaching listening, many research are conducted to examine 
the role of listening in first language acquisition and foreign language learning, and almost all of them concluded that listening is a vital and undeniable component of acquiring and mastering a language.

But the role of different types of listening input, different types of listening and listening genres and their profound effect on listening comprehension has been ignored throughout the years of teaching listening in listening classes. Brooks and Warren in their book "Modern Rhetoric,. (1979) describe genre as following: "a closed, formal system based definition on genre and its intention but described according to form: exposition, argumentation, description, narration."(p.223) Miller (1984) defines genre in summary as the followings: Genre is a conventional category of discourse based in large-scale categorization of rhetorical action; as action, it acquires meaning from situation and from the social context in which that situation happens. Students with different interests, backgrounds, talents and expectations might benefit from a specific kind of listening input, type of listening and listening genres. This research aims at finding out the effect of different listening types and different listening genres inputs on listening comprehension of EFL students. It is an attempt to find out if teaching different genres: (narrative, explanative, argumentative and expository) has any positive effect on listening comprehension of Iranian EFL students.

\section{METHODOLOGY}

\section{Materials and Methods:}

Introduction:

The purpose of this study was to see whether or not teaching four different genres of listening (narrative, argumentative, descriptive and expository) have any positive effect on the listening comprehension of Iranian EFL students. This section addresses the method adopted for this study. It introduces the participants, materials and instruments used in this study.

\section{Participants}

For the purpose of this study 2 homogeneous groups of intermediate EFL students were taken under study. The students signed up in language teaching institute (مدرس) and no information about the aim of the study. In order to make sure of the homogeneity of the students a pre-test of grammar and listening was given to students by the institute before the process of control and treatment began. Group A, treatment group containing 23 intermediate male students, aged between 17 and 28, received 12 sessions of genre-based listening input with an introduction to each genre features before each session of listening. Each session of listening lasted 90 minutes. Group B, control group containing 22 intermediate male students, aged between 19 and 26, received randomly selected genre based listening input which was given to treatment group but without any introductions to genres and their features, each session of listening lasted 90 minutes.

\section{Instrument}

As a pre-test, oxford placement test 1, by Dave Allan (2004) were applied for screening and placement of the students by the institute, total grade for grammar and listening test were 30 each, 60 in total. For the purpose of this study, the results of the listening part of the test were analyzed. For the post test, a combination of test from BARRON's TOEFL iBT Internet-based Test 2006-2007 $12^{\text {th }}$ edition listening section model tests and also Developing Skills for the TOEFL® iBT, transcripts, Listening Section were adopted.

\section{Materials}

For the purpose of this study genre based listening materials were carefully selected from three different sources. Source number 1, was Developing Skills for the TOEFL® iBT, transcripts, Listening Section, the second source was BARRON's TOEFL iBT Internet-based Test 2006-2007 $12^{\text {th }}$ edition listening section and the third source was Longman complete course for the toefl test listening section. For genre determination criteria Michigan's Genre Project Clarifying "Genre Study" and Identifying Teaching Points for ELA GLCE Genre version 12.5 and was used. Each of the genre inputs was selected from the text book according to their definitions and features.

\section{Procedure}

The procedure of conducting this study is explained in detail in this section, after forming two homogeneous intermediate classes, step by step of the teaching procedure is mentioned in this section.

\section{Group A, the treatment group:}

Group A, the treatment group, 23 male students received 12 sessions of genre based listening input. Each genre, narrative, argumentative, descriptive and expository received three sessions of genre based listening.

At the first three sessions, narrative genre was presented to the students, at the first session the features of narrative genre were introduced to the students: narrative genre forms, functions, and features were written on the board and a brief explanation was given about each form, function and feature. The functions of narrative genre in real life were introduced to students in the form of examples: story books, audio books, radio stories, etc. students could take notes and ask questions whenever they had difficulty in understanding parts of the genre introduction. then the session continued by listening to narrative listening input. The listening input was played via a central computer and students could listen to the input via their own computers. At the second session of practicing narrative form, a brief review of narrative genre features was reviewed for the students followed by listening to selected narrative listening input. At the third session of practicing narrative genre again a brief review of narrative genre features and function was covered for the students followed by answering students' questions about the genre or the listening input. In each session 20 
minutes of narrative listening input was played for students. Each input was played three times for students, the first time at a normal speed, the second time with appropriate pauses for students' memorization and the third time again at normal speed: After three times listening, related question to the listening input was asked from the students according to the class list in a random order, making sure that each student has answered at least one question. If a student answered a question incorrectly, the listening input was played again for him with appropriate pauses to see whether or not the student had realized the correct answer, if not students were asked to raise their hands if they knew the correct answer, after covering the correct answer the listening input and the correct answer was reviewed for students with enough explanations for them to realize the cause of the incorrect answer.

Other three genres on argumentative, descriptive and expository were practiced in the same procedure as narrative genre; However, when practicing expository genre which shares some characteristics with descriptive genre, a thorough description of both genres were introduced to the students and their most prominent differences were highlighted and practiced.

\section{Group B, the control group:}

Group B, the control group received 12 sessions of randomly selected genre based listening input. The materials were selected from argumentative, descriptive, narrative and expository genres which were presented to the treatment group (Group A) but presented in random order and without any introduction to genres and their features. For example session one covered an audio input in the argumentative genre, the second session expository genre input was presented to students and so on. Each session difficult or new vocabulary was introduced to students. Each listening input was played 3 times, the first time in normal speed, the second time with appropriate pauses and the third time again with normal speed for the sake of students' memorization. Incorrect answers were corrected by listening to the related part of the input and asking students to correct the given question by the help of the instructor. Each student had to at least answer one question in each session of listening.

\section{RESULTS AND ANALYSIS}

\section{Results and discussions:}

For this study independent T-test is performed on both the results of pre-test on control and treatment group and also on the results of post-test of treatment and control group. Independent t-test has four assumptions; 1) The data should be measured on an interval scale; 2) The subjects should be independent that is to say their performance on the test is not affected by the performance of other students, 3) The data should enjoy normal distribution and 4) The groups should have homogeneous variances. (Flucher and Davidson, 2007) The present data are measured on an interval scale and none of the subjects' performs independently on the tests. The assumption of normality is also met. A lot of statistical tests (e.g. t-test) require that our data are normally distributed and therefore we should always check if this assumption is violated. As displayed in Table 1 the values of Skewness and kurtosis are within the ranges of $+/-2$ (7) (Bachman, 2005) hence the normality of the present data.

TABLE 1

NORMALITY TESTS

\begin{tabular}{|c|c|c|c|c|c|c|}
\hline \multirow[t]{2}{*}{ Groups } & & \multirow{2}{*}{\begin{tabular}{|l|}
$\mathbf{N}$ \\
Statistic \\
\end{tabular}} & \multicolumn{2}{|l|}{ Skewness } & \multicolumn{2}{|l|}{ Kurtosis } \\
\hline & & & Statistic & Std. Error & Statistic & Std. Error \\
\hline \multirow{2}{*}{ Experimental } & Pretest & 23 & .092 & .481 & -1.107 & .935 \\
\hline & Posttest & 23 & -.375 & .481 & -.647 & .935 \\
\hline \multirow{2}{*}{ Control } & Pretest & 22 & -.436 & .491 & .216 & .953 \\
\hline & Posttest & 22 & -.111 & .491 & -.902 & .953 \\
\hline
\end{tabular}

The assumption of homogeneity of variances will be discussed when reporting the results of the independent t-test.

\section{Pretest of Listening}

Before starting to present the treatment to treatment group, an independent t-test is run to compare the mean scores of the experimental and control groups on the pretest of listening in order to prove that the two groups were homogenous in terms of their listening ability prior to the main study.

As displayed in Table 2 the mean scores for experimental and control groups on pretest of listening are 13.48 and 13.68 respectively.

TABLE 2:

DESCRIPTIVE STATISTICS PRETEST OF LISTENING BY GROUPS

\begin{tabular}{|l|l|l|l|l|}
\multicolumn{5}{c}{ DESCRIPTIVE STATISTICS PRETEST OF LISTENING BY GROUPS } \\
\hline Group & $\mathbf{N}$ & Mean & Std. Deviation & Std. Error Mean \\
\hline Experimental & $\mathbf{2 3}$ & $\mathbf{1 3 . 4 8}$ & $\mathbf{4 . 6 6 0}$ & $\mathbf{9 7 2}$ \\
\hline Control & $\mathbf{2 2}$ & $\mathbf{1 3 . 6 8}$ & $\mathbf{3 . 9 4 5}$ &. $\mathbf{8 4 1}$ \\
\hline
\end{tabular}

The results of the independent $\mathrm{t}$-test $(\mathrm{t}(43)=.158, \mathrm{P}=.87>.05)$ indicate that there was not any significant difference between experimental and control groups' mean scores on the pretest of listening. Thus it can be concluded that the two groups enjoyed the same level of listening ability prior to the main study. 
TABLE 3

INDEPENDENT T-TEST PRETEST OF LISTENING BY GROUPS:

\begin{tabular}{|c|c|c|c|c|c|c|c|c|c|}
\hline & \multicolumn{2}{|c|}{$\begin{array}{l}\text { Levene's Test for Equality } \\
\text { of Variances }\end{array}$} & \multicolumn{7}{|c|}{ t-test for Equality of Means } \\
\hline & \multirow[t]{2}{*}{$\mathbf{F}$} & \multirow[t]{2}{*}{ Sig. } & \multirow[t]{2}{*}{$\mathbf{T}$} & \multirow[t]{2}{*}{ Df } & \multirow[t]{2}{*}{$\begin{array}{l}\text { Sig. (2- } \\
\text { tailed) }\end{array}$} & \multirow[t]{2}{*}{$\begin{array}{l}\text { Mean } \\
\text { Difference }\end{array}$} & \multirow[t]{2}{*}{$\begin{array}{l}\text { Std. Error } \\
\text { Difference }\end{array}$} & \multicolumn{2}{|c|}{$\begin{array}{l}95 \% \text { Confidence Interval } \\
\text { of the Difference }\end{array}$} \\
\hline & & & & & & & & Lower & Upper \\
\hline $\begin{array}{l}\text { Equal variances } \\
\text { assumed }\end{array}$ & 1.241 & .271 & .158 & 43 & .875 & .204 & 1.290 & -2.398 & 2.805 \\
\hline $\begin{array}{l}\text { Equal variances } \\
\text { not assumed }\end{array}$ & & & .158 & 42.388 & .875 & .204 & 1.285 & -2.389 & 2.796 \\
\hline
\end{tabular}

It should be noted that the assumption of homogeneity of variances is met (Levene's $\mathrm{F}=1.24, \mathrm{P}=.271>.05 ; \mathrm{r}=.02$ it represents a weak effect size). That is why the first row of Table 3, i.e. "Equal variances assumed" is reported.

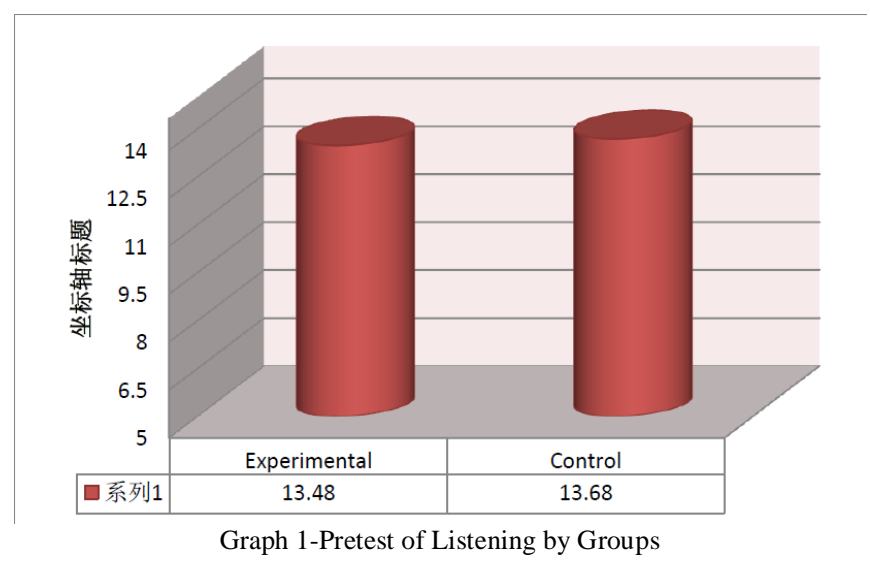

\section{Research question}

The underlying question of this study is presented in the following form:

Do teaching different listening genres have any effect on listening for detailed information of EFL students?

In order to answer the above research question, an independent t-test is run to compare the mean scores of the experimental and control groups on the post-test of listening in order to probe the effect of teaching different listening genres on listening for detailed information of EFL students. As displayed in Table 4 the mean scores for experimental and control groups on pretest of listening are 18.43 and 14.41 respectively.

TABLE 4.

DESCRIPTIVE STATISTICS POST-TEST OF LISTENING BY GROUPS

\begin{tabular}{|l|l|l|l|l|}
\hline Group & $\mathbf{N}$ & Mean & Std. Deviation & Std. Error Mean \\
\hline Experimental & 23 & 18.43 & 4.241 & .884 \\
\hline Control & 22 & 14.41 & 3.887 & .829 \\
\hline
\end{tabular}

The results of the independent $\mathrm{t}$-test $(\mathrm{t}(43)=3.31, \mathrm{P}=.002<.05 ; \mathrm{r}=.45$ it represents an almost large effect size) indicate that there is a significant difference between experimental and control groups' mean scores on the posttest of listening. The null-hypothesis as teaching different listening genres does not have any effect on listening for detailed information of EFL students is rejected. The treatment group after receiving listening genres outperformed the control group on the post-test of listening comprehension.

TABLE 5

INDEPENDENT T-TEST PRETEST OF LISTENING BY GROUPS

\begin{tabular}{|c|c|c|c|c|c|c|c|c|c|}
\hline & \multicolumn{2}{|c|}{$\begin{array}{l}\text { Levene's Test for } \\
\text { Equality of Variances }\end{array}$} & \multicolumn{7}{|c|}{ t-test for Equality of Means } \\
\hline & \multirow[t]{2}{*}{$\mathbf{F}$} & \multirow[t]{2}{*}{ Sig. } & \multirow[t]{2}{*}{$\mathbf{T}$} & \multirow[t]{2}{*}{ Df } & \multirow[t]{2}{*}{$\begin{array}{l}\text { Sig. (2- } \\
\text { tailed) }\end{array}$} & \multirow[t]{2}{*}{$\begin{array}{l}\text { Mean } \\
\text { Difference }\end{array}$} & \multirow[t]{2}{*}{$\begin{array}{l}\text { Std. Error } \\
\text { Difference }\end{array}$} & \multicolumn{2}{|c|}{$\begin{array}{l}95 \% \text { Confidence Interval of } \\
\text { the Difference }\end{array}$} \\
\hline & & & & & & & & Lower & Upper \\
\hline $\begin{array}{l}\text { Equal variances } \\
\text { assumed }\end{array}$ & .202 & .656 & 3.315 & 43 & .002 & 4.026 & 1.214 & 1.577 & 6.475 \\
\hline $\begin{array}{l}\text { Equal variances } \\
\text { not assumed }\end{array}$ & & & 3.322 & 42.926 & .002 & 4.026 & 1.212 & 1.581 & 6.470 \\
\hline
\end{tabular}

It should be noted that the assumption of homogeneity of variances is met (Levene's $\mathrm{F}=.202, \mathrm{P}=.656>.05$ ). That is why the first row of Table 5, i.e. "Equal variances assumed" is reported. 


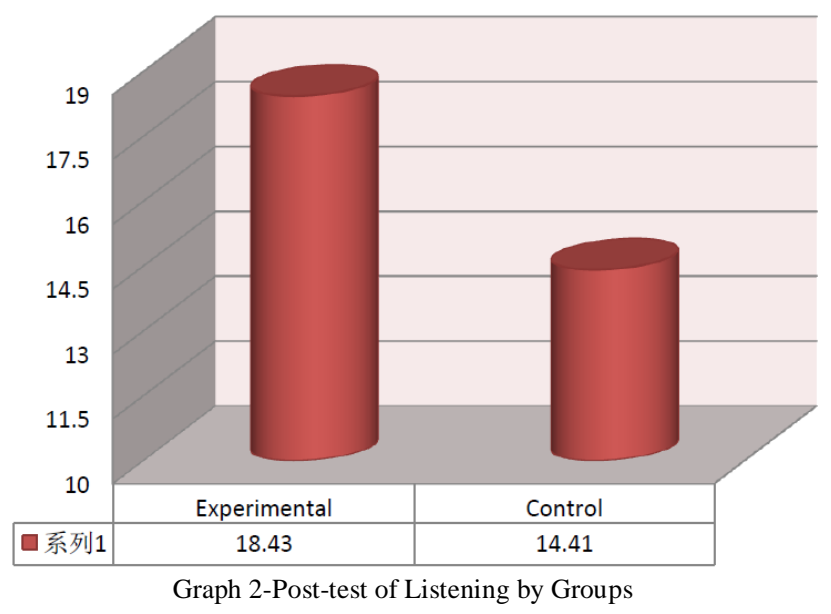

In this study, the Group A, the treatment group, received 12 sessions of genre based listening input. Group B, the control group also received 12 session of genre based input, but the genres were presented in random order and without any introduction to genres and their specification. In order to make sure of the homogeneity of the two groups a pre-test was given to both groups. A lot of statistical tests (e.g. t-test) require that our data are normally distributed and therefore we should always check if this assumption is violated. Skewness and kurtosis data are considered normal only if the value are within the range of +2 and -2 As displayed in Table 1 the values of Skewness and kurtosis are within the ranges of $+/-2$ (Bachman 2005), hence the normality of the present data.

The results of the independent t-test on pre-test is thoroughly described in Table 2 which is a Descriptive Statistics Pretest of Listening by groups, $(\mathrm{t}(43)=.158, \mathrm{P}=.87>.05)$ indicate that there was not any significant difference between experimental and control groups' mean scores 13.48 and 13.68 on the pretest of listening. Graph 1 also clearly shows that both treatment and control group performed identical on the pre-test. Thus it can be concluded that the two groups enjoyed the same level of listening ability prior to the main study and there were no meaningful difference between the two groups in the pre-test

Post-test results of the treatment group t-test is presented in table 3 shows that $(\mathrm{t}(43)=3.31, \mathrm{P}=.002<.05 ; \mathrm{r}=.45$ which represents an almost large effect size, indicate that there is a significant difference between treatment and control groups' mean scores (treatment group: 18.43 control group: 14.41) on the post-test of listening, also Graph 2 clearly shows that the treatment group performed significantly better than control group after receiving the treatment of genres and therefore the null-hypothesis: teaching different listening genres does not have any effect on listening comprehension of EFL students is rejected.

\section{Discussions AND CONCLUSIONS}

\section{Discussion}

The results of this proved that introducing different genres to students in listening form is beneficial for language learners. Research on the effects of genre happened to be extremely rare to find when looking for prior research on genre and listening comprehension. Reasons for this might be the fact that perhaps developing genre based listening input is very difficult and time consuming, which was also a problem in the procedure of this research. Lack of proper genre based materials will cause problems for researchers trying to conduct their own research on genre based listening comprehension classes. The findings of this study are compared with the findings of prior studies on genre on reading and writing due to lack of enough prior research on the effect of teaching genres and listening comprehension. Here a brief comparison is done to see how current research corresponded with prior research on genres and their effects.

Overall, the study indicates that the fourth grade reading comprehension problem is at least partially attributable to the emergence of complex dependencies between the nature of the text and the reader's prior knowledge. Introducing the genre of the listening and its features leads to activation of students' prior knowledge which might help them to comprehend the listening input easier. On writing (20) (Paltridge, 1996), also encourages the application of genres in reading classes and states that "Students may, equally, be given a number of examples of a particular genre and asked to identify the generic structure and associated text type/s on the basis of their examination of the texts. In this way students can explore the characteristic features of particular genres, and the sorts of variation that occur within them." In this study also students were introduced to four genres of narrative, argumentative, descriptive and expository but in listening form and also examples of particular genres were given to students, so they could be able to identify each genre and adopt the most appropriate listening comprehension strategy to understand them. Lin, (2006) conducted a study on 6 genres of writing: narratives tell a story, usually to entertain, recounts (Personal, Factual) tell what happened, information reports provide factual information, instructions tell the listener or reader what to do, explanations explain how or why something happens, expository texts The conclusion of the research was "The students, in their assignments 
and examinations, produce good coherent writing in the genres taught, usually relying on the model texts provided. The writing of the best students even under examination conditions is impressive, showing ability to adapt the features learnt for their own communicative purposes. In this study, again genres were introduced to students in writing format, in current research however; genres were introduced in listening format and positive effects were also observed in this research. The findings of this study easily is in agreement with the findings of previous research on genre and its effect on language learning/acquisition with the exception that previous research were almost conducted on reading and writing process. This research on the other hand, tried to discover the effect of genre on listening comprehension of language learners. Based on the results of this study it can be stated that genres have significant effects on listening comprehension of EFL students and including the genre could be as beneficial and helpful in listening as it is in reading and writing. By defining the genre of the listening input and its features and functions, we can make the process of listening comprehension more meaningful for the language learners. Also introducing genres could be a good warm up exercise for starting the listening comprehension classroom.

\section{REFERENCES}

[1] Afflerbach, P. (1990). The influence of prior knowledge and text genre on readers' prediction strategies. Journal of Literacy Research. 1990 22: 131

[2] Allan, D. (2004). Oxford Placement test1. Oxford University Press 2004.Oxford University.

[3] Bachman, L, F. (2005). Fundamental Considerations in Language Testing. Oxford University Press 2005.Oxford University.

[4] Best, R, Ozuru, Y, Floyd R, G, and McNamara, D, S. (2002). Children's Text Comprehension: Effects of Genre, Knowledge, and Text Cohesion. ICLS '06 Proceedings of the 7th international conference on Learning sciences Pages 37-42.

[5] Brooks, M and Warren, R, P. (1979). "Modern Rhetoric, 4th ed. Harcourt Brace Jovanovich, 1979 - Language Arts \& Disciplines.

[6] Brown, S. (2006). Teaching Listening. Cambridge University press Cambridge, New York, Melbourne, Madrid, Cape Town, Singapore, São Paulo.

[7] Developing Skills for the TOEFL® iBT TRANSCRIPTS Listening Section / Speaking Section / Writing Section.

[8] Feyten, C. (1991). The power of listening ability: an overlooked dimension in language acquisition. The Modern Language Journal, 75 (2): 173-180.

[9] Flowerdew, J. (1993). An educational, or process, approach to the teaching of professional genres. ELT Journal Volume 47/4 October 1993 (C) Oxford University Press 1993.

[10] Flucher, G and Davidson, F. (2007). Language Testing and Assessment An advanced resource book. by Routledge 2 Park Square, Milton Park, Abingdon, Oxon OX14 4RN.

[11] Firkins, A, Forey, G, and Sengupta, S. (2007). A Genre-Based Literacy Pedagogy: Teaching Writing to Low Proficiency EFL Students. English Language Teaching Journal, Oct 2007.Issue 4,225-348.

[12] Graham-Marr, A. (2004). Communication Spotlight Pre Intermediate SB. Abax (April 1, 2006). ISBN 10: 1896942199ISBN13: $978-1896942193$.

[13] Lingzhu, J. (2009). Genre-based Approach for Teaching English Factual Writing. Humanizing language teaching. Issue 2; April 2009:25-73, ISSN 1755-9715,15-42.

[14] Liu, J. (2004). Effect of comic strips on L2 learners' reading comprehension. TESOL QUARTERLY Vol.38, No. 2:, summer 2004:10-39.

[15] Longman Complete Course for the TOEFIY Test: Preparation for the Computer and Paper Tests Copyright @ 200] by AddisonWesley Longman, Inc. A Pearson Education Company.

[16] McNamar, D, S, Ozuru, Y and Floyd, R, G. (2011). Comprehension challenges in the fourth grade. The roles of text cohesion, text genre, and readers' prior knowledge. International Electronic Journal of Elementary Education, 4(1), 229-257.

[17] Miller, C, R. (1984). Genre as social action. Quarterly journal of speech.70 (1984), 151-167.

[18] Michigan's Genre Project Clarifying "Genre Study" and Identifying Teaching Points for ELA GLCE Genre. v.12.05. Office of School Improvement.www.michigan.gov/mde.

[19] Paltridge, B. (1996). Genre, text type, and the language learning classroom. ELT Journal Volume 50/3 July 1996 @) Oxford University Press 1996:90-115.

[20] Poelmans, P. (2003). Developing second-language listening comprehension: Effects of training lower-order skills versus higher-order strategy. ISBN 90-76864-36-5 NUR 632.

[21] Richards, JC. (2008). Teaching Listening and Speaking From Theory to Practice. Cambridge University press Cambridge, New York, Melbourne, Madrid, Cape Town, Singapore, São Paulo.

[22] Sharpe, P, J. (2007). BARRON'S TOFEL iBT Internet-Based Test 2006-2007 $12^{\text {th }}$ edition.

[23] Zare-ee, A. (2009). The Effects of Teaching Genre Moves on EFL Learners' Performance in Letter Writing. Pazhuhesh-e Zabanha-ye Khareji, No. 49, Special Issue, English, Winter 2009, pp. 43-64.

Bahador Sadeghi, an assistant professor of Applied Linguistics holds a doctorate degree in TEFL from the University of Isfahan, Iran. He also holds three MAs in TEFL, English Translation and International Relations from Tehran Islamic Azad University, Isfahan University and Allameh Tabatabai University respectively. He has been lecturing different subjects in TEFL, Translation studies, General English and ESP at several universities in Iran for the last twenty years. He has both published and presented a number of articles in some international journals and conferences. He has translated twenty books from English to Persian. He is also a certified translator to the judiciary power in Iran and he has been, as a simultaneous interpreter, actively involved in many national and international seminars, sport events and tourism projects. 
Mohammad Taghi Hassani, assistant professor in TEFL at Imam Hossein University, Tehran and Islamic Azad University, Takestan Branch, Iran. His research interests are EFL writing, psycholinguistics, phonetics, contrastive analysis, English for Specific Purposes, and language teaching methodology.

Hessam Noory received his BA in 2010 and MA in 2013 in TEFL from the Department of English Language at Islamic Azad University of Takestan. He is currently teaching English at private schools and high schools in Karaj, Iran. 